\title{
Ocean-atmosphere climate shift during the mid-to-late Holocene transition
}

\author{
Audrey Morley ${ }^{\mathrm{a}, *, 1}$, Yair Rosenthal ${ }^{\mathrm{a}}$, Peter deMenocal ${ }^{\mathrm{b}}$ \\ a Institute of Marine and Coastal Sciences and Department of Earth and Planetary Sciences, Rutgers, The State University of New Jersey, 71 Dudley Road, \\ New Brunswick, NJ 08901, USA \\ ${ }^{\mathrm{b}}$ Earth and Environmental Sciences, Lamont-Doherty Earth Observatory, Columbia University, Earth Institute, 61 Route 9W, PO Box 1000, Palisades, NY \\ 10964-8000, USA
}

\section{A R T I C L E I N F O}

\section{Article history:}

Received 6 May 2013

Received in revised form 14 November 2013

Accepted 19 November 2013

Available online $\mathrm{xxxx}$

Editor: J. Lynch-Stieglitz

\section{Keywords:}

paleoceanography

ocean-atmosphere climate linkages

mid-Holocene climate optimum

Eastern North Atlantic Central water

circulation

NAO

orbital insolation

\begin{abstract}
A B S T R A C T
Climate records of the mid-to-late Holocene transition, between 3-4 thousand years before present (ka), often exhibit a rapid change in response to the gradual change in orbital insolation. Here we investigate North Atlantic Central Water circulation as a possible mechanism regulating the latitudinal temperature gradient (LTG), which, in turn, amplifies climate sensitivity to small changes in solar irradiance. Through this mechanism, sharp climate events and transitions are the result of a positive feedback process that propagates and amplifies climate events in the North Atlantic region. We explore these linkages using an intermediate water temperature record reconstructed from $\mathrm{Mg} / \mathrm{Ca}$ measurements of benthic foraminifera (Hyalinea balthica) from a sediment core off NW Africa ( $889 \mathrm{~m}$ depth) between 0 to $5.5 \mathrm{ka}$. Our results show that Eastern North Atlantic Central Waters (ENACW) cooled by $\sim 1^{\circ} \pm 0.7^{\circ} \mathrm{C}$ and densities decreased by $\sigma_{\theta}=0.4 \pm 0.2$ between 3.3 and $2.6 \mathrm{ka}$. This shift in ENACW hydrography illustrates a transition towards enhanced mid-latitude atmospheric circulation after $2.7 \mathrm{ka}$ in particular during cold events of the late-Holocene. The presented records demonstrate the important role of ENACW circulation in propagating the climate signatures of the LTG by reducing the meridional heat transfer from high to low latitudes during the transition from the Holocene Thermal Maximum to the late-Holocene. In addition, the dynamic response of ENACW circulation to the gradual climate forcing of LTGs provides a prime example of an amplifying climate feedback mechanism.
\end{abstract}

Published by Elsevier B.V.

\section{Introduction}

Observations over the past century indicate that changes in the North Atlantic Oscillation (NAO), exert the dominant control on the path and strength of the mid-latitude Westerlies and climate in the North Atlantic on interannual to decadal timescales (Hurrell, 1995; Visbeck et al., 2003). The region with the strongest response to NAO-modulated wind-stress is the northeastern subpolar basin of the Atlantic Ocean, where the strength of the Icelandic Low enhances westerly air flow by up to $8 \mathrm{~ms}^{-1}$ (Hurrell, 1995) and thereby lowers sea surface temperatures (SST) by several tenths of degrees $\left(\sim 0.7^{\circ} \mathrm{C}\right)$ during extremely positive NAO $(+)$ years (Furevik and Nilsen, 2005; Johnson and Gruber, 2007). Subpolar Mode Water (SPMW) which forms in this region during winter convection (Tomczak and Godfrey, 1994) is thus highly susceptible to NAO phase shifts, and carries the signature of the atmospheric NAO pattern in its properties (e.g. temperature and salin-

\footnotetext{
* Corresponding author. Tel.: +1 8489323401.

E-mail address: audrey.morley@nuigalway.ie (A. Morley).

1 Now at School of Geography and Archaeology, National University of Ireland Galway, Galway, Ireland.
}

ity) (Johnson and Gruber, 2007). After formation SPMW comprises a large fraction of Eastern North Atlantic Central Water (ENACW) (Iselin, 1936; Poole and Tomczak, 1999).

ENACW integrates interannual NAO variability as smoother, longer-term multidecadal (60-to-90-year) oscillations (Morley et al., 2011). On these timescales the oceanic signature of positive NAO phases is associated with a tripole pattern of cold SST anomalies in the subpolar North Atlantic, warm anomalies in the West Atlantic between 20 and $45^{\circ} \mathrm{N}$, and cold anomalies between 0 and $30^{\circ} \mathrm{N}$ in the East Atlantic (Marshall et al., 2001). On multidecadal timescales the oceanic signature of the NAO is captured by the Atlantic Multidecadal Oscillation (AMO) (Grossmann and Klotzbach, 2009; Marshall et al., 2001). The AMO describes basin-wide SST and sea level pressure anomalies, with warm anomalies during positive and cold anomalies during negative phases (Knight et al., 2005; Knudsen et al., 2011; Kushnir, 1994; Olsen et al., 2012). The intensity of mid-latitude Westerlies, strongest during positive NAO phases reinforce cold SST anomalies during AMO (-) (Häkkinen, 2000). In this way long-term positive phases of the NAO are linked to the negative phase of the AMO. However the precise forcing mechanism behind multidecadal SST variability in the North Atlantic including natural variability in the Atlantic Meridional 
Overturning Circulation, solar variability, and/or volcanism remains uncertain (Booth et al., 2012; Grossmann and Klotzbach, 2009; Ottera et al., 2010; Sicre et al., 2011). On centennial timescales, there is evidence (Ammann et al., 2007; Knudsen et al., 2009; Lockwood et al., 2010; Lohmann et al., 2004; Swingedouw et al., 2010) for the existence of similar ocean-atmosphere linkages that communicate and amplify relatively small changes in total solar irradiance ( $\Delta$ TSI) into a climate signal extending beyond the northeastern Atlantic region (Lean, 2010; Morley et al., 2011; Shindell et al., 2001). A common approach to identify and interpret past climate records is to match proxy based climate reconstructions with modern ocean-atmosphere circulation modes such as the oceanic expressions of the NAO-AMO (Luterbacher et al., 2004; Mann et al., 2009; Trouet et al., 2009) or $\Delta$ TSI (Lean, 2010; Shindell et al., 2001; Steinhilber et al., 2012, 2009), recognizing that often these trends are far longer than the intrinsic interannual or multidecadal NAO-AMO variability.

The presence of non-NAO-AMO-like atmospheric variability in modern instrumental records provides a first indication that the focus on the NAO-AMO for past climate reconstructions may be too simplistic. Instrumental observations show for example that the relationship between the NAO and the strength of the midlatitude Westerlies periodically breaks down, most prominently during the 1930s (American Dust Bowl) and more recently over the last decade (2000 to 2012) indicating the possibility of a different atmospheric circulation pattern operating during these times (Bengtsson et al., 2004; Drinkwater, 2006; Overland and Wang, 2005; Wood and Overland, 2010). During both periods, high latitudes experienced peak warming and sea ice loss (Barents Sea) in the absence of a positive NAO mode (Bengtsson et al., 2004; Overland and Wang, 2005). Similarly, high latitude warming and reduced Arctic sea ice extent prevailed during the Holocene Thermal Maximum (HTM) between 11 and 4 ka (Andersen et al., 2004a; Koç et al., 1993; Polyak and Mikhailov, 1996; Voronina et al., 2001), when high northern summer insolation was stronger and the latitudinal temperature gradient (LTG) (e.g. the difference in temperature between the high Arctic and the Tropics) was weaker than today (Davis and Brewer, 2009; Fischer and Jungclaus, 2011). The most recent analogue to a decrease in the LTG occurred during the 1930s (Rind, 1998) and more prominently during the past decade (Section 5.2).

Unlike the 1930s however several proxy and numerical based climate reconstructions propose that strong mid-latitude Westerlies $(\mathrm{NAO}+)$ prevailed during the warm HTM. Likewise the cooler late-Holocene is often associated with weaker westerly airflow (NAO -) (Renssen et al., 2005b; Rimbu et al., 2003, 2004; Wanner et al., 2008) whereas other records provide evidence for enhanced atmospheric circulation over North Atlantic mid- and highlatitudes during the late-Holocene (Brayshaw et al., 2010; De Angelis et al., 1997; Jennings et al., 2011; Moros et al., 2012; Renssen et al., 2005a). These conflicting interpretations suggest that the focus on the NAO-AMO as a modern analogue for the Holocene may oversimplify past climate dynamics (Pinto and Raible, 2012).

Morley et al. (2011) showed that past temperatures and the oxygen isotopic composition $\left(\delta^{18} \mathrm{O}_{\mathrm{sw}}\right)$ of ENACW recorded off the Northwest African continental margin are determined by SPMW formation south and west of Iceland on both instrumental, multidecadal and multicentennial timescales over the past millennium. Essentially, ENACW circulation provides an 'oceanic tunnel' (Liu and Alexander, 2007) transmitting subpolar ocean-atmospheric climate anomalies to lower latitudes. Here we extend the investigation of ENACW variability over the past $5.5 \mathrm{ka}$ to test the hypothesis that ENACW cooling (warming) during the Holocene enhances (reduces) the LTG and thereby amplifies climate sensitivity to small changes in insolation, creating a positive feedback loop that propagates and amplifies climate events in the North

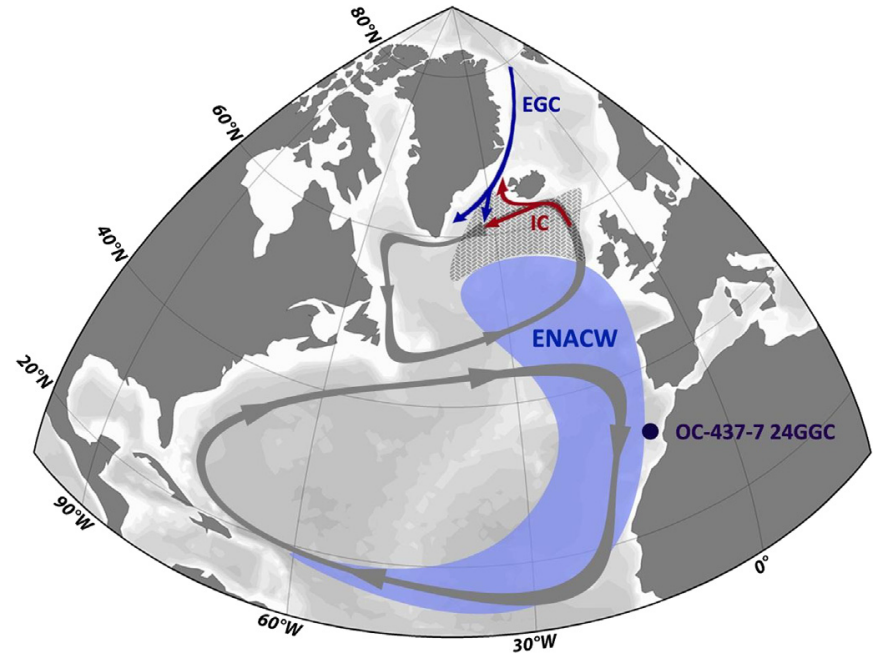

Fig. 1. Map of core location and schematic representation of the shallow overturning circulation in the North East Atlantic. The Eastern North Atlantic Central Water (ENACW) formation region is marked in light grey hatching and represents the area where SPMW form and winter surface water densities range between $\sigma_{\Theta}=27.3$ and 27.7 (adapted from McCartney and Talley, 1982). The influence and circulation of ENACW (blue) represents potential density surfaces between $\sigma_{\Theta}=27.3$ and 27.7 at mid-depth (adapted from Keffer, 1985). The location and flow of the East Greenland Current (EGC) and the Irminger Current (IC) are marked in blue and red arrows respectively. (For interpretation of the references to color in this figure legend, the reader is referred to the web version of this article.)

Atlantic region. To test this hypothesis we present a combination of modern observations alongside a $5.5 \mathrm{ka}$ long paleotemperature and stable isotopic record based on benthic foraminifera collected within ENACW (889 m water depth) from the northwest African continental shelf in the eastern boundary of the subtropical gyre (STG) (Fig. 1). By analyzing and comparing our data with a wide range of proxy records in our discussion (both in terms of geographic locations and in proxy variety) we will investigate the possible link between gradually changing LTGs during the winter and the transmission of North Atlantic climate change at central water depth. Specifically, we focus on the transition from the HTM to the colder late-Holocene (or the mid-to-late Holocene transition) at subpolar latitudes between 3.5 and 4 ka (Came et al., 2007; Giraudeau et al., 2010; Ólafsdóttir et al., 2010; Pena et al., 2010).

\section{Materials and methods}

\subsection{Oceanographic setting}

Gravity core OC437-7 24GGC was collected at $889 \mathrm{~m}$ water depth $\left[30.854^{\circ} \mathrm{N}, 10.272^{\circ} \mathrm{W}\right]$ in the eastern boundary of the STG during the CHEETA (Changing Holocene Environments of the Eastern Tropical Atlantic) coring cruise on the R/V Oceanus in July 2007 (McGee et al., 2013). At 889 m water depth ENACW is the dominant water mass at the core site, with average temperature and salinity values near $7.8-7.9^{\circ} \mathrm{C}$ and 35.45 psu respectively. Cross-gyre transfer of subsurface ENACW (Keffer, 1985; McCartney and Talley, 1982; McDowell et al., 1982) occurs via SPMW formation in the eastern SPG between density surfaces $\sigma_{\theta}$ 27.3 and $27.6 \mathrm{~kg} / \mathrm{m}^{3}$ (Levitus, 1989; McCartney and Talley, 1982). ENACW formation and circulation thus establishes a direct link between both gyres and allows us to investigate the influence of subpolar ocean-atmosphere climate linkages on ENACW properties and cross gyre climate signal propagation. ENACW is underlain by a salinity minimum signaling the upper limit of Antarctic Intermediate Water (AAIW) between 900 and $1300 \mathrm{~m}$ (Knoll et al., 2002). Below this, the very high salinity Mediterranean Outflow Water (MOW) occurs near 1300 m (Arhan et al., 1994; 
Table 1

AMS ${ }^{14} \mathrm{C}$ radiocarbon dates for OC437-7 24GGC.

\begin{tabular}{|c|c|c|c|c|c|c|c|c|}
\hline Lab ID $^{*}$ & Core & $\begin{array}{l}\text { Depth } \\
(\mathrm{cm})\end{array}$ & $\begin{array}{l}\text { Species } \\
\text { (planktic) }\end{array}$ & $\begin{array}{l}\text { Radiocarbon age } \pm 1 \sigma \text { error } \\
\text { (yr BP) }\end{array}$ & $\begin{array}{l}\text { Calibrated age WMA } \\
\text { (cal. kyr BP) }\end{array}$ & $\begin{array}{l}2 \sigma \text { range } \\
(\text { cal. kyr } \mathrm{BP})\end{array}$ & $\begin{array}{l}\text { Adjusted age } \\
\text { model }\end{array}$ & $\begin{array}{l}\text { Reference for original } \\
\text { radiocarbon dates }\end{array}$ \\
\hline 158069 & OC437-7 24GGC & 32.5 & G. bulloides & $1005 \pm 35$ & 586 & 524-647 & 586 & This study \\
\hline 158070 & OC437-7 24GGC & 118.5 & G. bulloides & $2430 \pm 45$ & 2070 & $1930-2218$ & 2218 & This study \\
\hline 158071 & OC437-7 24GGC & 222.5 & G. bulloides & $4120 \pm 40$ & 4180 & $4054-4339$ & 4339 & This study \\
\hline 158072 & OC437-7 24GGC & 294.5 & G. bulloides & $4890 \pm 110$ & 5183 & $4875-5458$ & 5420 & This study \\
\hline
\end{tabular}

Center for Accelerator Mass Spectrometry, Lawrence Livermore National Laboratory.

Knoll et al., 2002). Modern seasonal and inter-annual variability in temperature and salinity are small at $900 \mathrm{~m}$ water depth (Knoll et al., 2002) and there is no indication for changing water masses at the core site over the past $6 \mathrm{ka}$. Please see Appendix A for a detailed discussion on the possible influence of AAIW and MOW at our core site during the past $6 \mathrm{ka}$.

\subsection{Paired $\mathrm{Mg} / \mathrm{Ca} \delta^{18} \mathrm{O}$ measurements}

We reconstructed ENACW temperature during the past $5.5 \mathrm{ka}$ by measuring $\mathrm{Mg} / \mathrm{Ca}$ and oxygen isotopic values $\left(\delta^{18} \mathrm{O}_{\mathrm{c}}\right)$ on the benthic foraminifera Hyalinea balthica, a shallow infaunal benthic foraminifera living within the top $1.5 \mathrm{~cm}$ of oxygenated, nutrient rich, fine grained sediments (Schmiedl et al., 2000; Villanueva Guimerans and Cervera Currado, 1999). Rosenthal et al. (2011) found no significant difference in $\mathrm{Mg} / \mathrm{Ca}$ and $\delta^{18} \mathrm{O}_{\mathrm{c}}$ between specific size fractions from the same sample. Accordingly we measured approximately 5 to 10 specimens of $H$. balthica $(>150 \mu \mathrm{m})$ from each sample for stable oxygen isotope analysis at the Department of Earth and Planetary Sciences at Rutgers University. All samples were reacted in phosphoric acid at $90^{\circ} \mathrm{C}$ (for $15 \mathrm{~min}$ ) in an automated peripheral attached to a Micromass Optima mass spectrometer and stable isotope values of calcite are reported versus V-PDB. The $1 \sigma$ precision of standards analyzed during automated runs is $0.08 \%$ for $\delta^{18} \mathrm{O}_{\mathrm{c}}$. Comparing the $\delta^{18} \mathrm{O}_{\mathrm{c}}$ record of $H$. balthica from OC437-7 24GGC to GeoB6007-2 (Morley et al., 2011) we adjusted the former by adding $0.1 \%$ o to all the data to account for an inter-laboratory offset (Rosenthal et al., 2011).

For trace metal analysis, we analyzed up to 25 (mean: 20 individuals) $H$. balthica tests from the 250-350 $\mu \mathrm{m}$ size fraction, using a modified reductive, oxidative cleaning protocol (Barker et al., 2003) and a Sector Field Inductively Coupled Plasma Mass Spectrometer (Thermo Element XR) at Rutgers Inorganic Analytical Laboratory, following the methods outlined in Rosenthal et al. (1999). The long-term analytical precision of $\mathrm{Mg} / \mathrm{Ca}$ ratios is based on repeated analysis of three consistency standards of $\mathrm{Mg} / \mathrm{Ca}$ concentrations of $1.10,2.40$ and $6.10 \mathrm{mmol} \mathrm{mol}^{-1}$. Over the course of this study, the precision for the consistency standards was 0.29 , 0.64 and $0.62 \%$ RSD (relative standard deviation) respectively. For paleotemperature reconstructions the equation $\mathrm{Mg} / \mathrm{Ca}=0.49 \mathrm{~T}$ $\left({ }^{\circ} \mathrm{C}\right)$ was used (Rosenthal et al., 2011). For standard-error estimates for paleotemperature, the oxygen isotopic composition of seawater $\left(\delta^{18} \mathrm{O}_{\mathrm{sw}}\right)$, salinity and density values $\left( \pm 0.7^{\circ} \mathrm{C}, \pm 0.3 \%\right.$, $\pm 0.7 \mathrm{psu}$ and $\sigma_{\theta}= \pm 0.3$ ), we followed standard error propagation calculations for a quadratic paleotemperature equation (Shackleton, 1974). For salinity reconstructions of ENACW we use the relationship of $\delta^{18} \mathrm{O}_{\mathrm{sw}}(\%$ SMOW $)=0.55 \mathrm{~S}-18.98$, which we derived from the LeGrande and Schmidt (2006) gridded $\delta^{18} \mathrm{O}_{\mathrm{sw}}$ dataset for the Cape Ghir region. Using this relationship and paired $\mathrm{Mg} / \mathrm{Ca}-\delta^{18} \mathrm{O}_{\mathrm{c}}$ measurements on H. balthica from the core-top sample in OC437-7 24GGC, we obtain a modern bottom water salinity of 35.69 psu. Compared to modern salinity values at Cape Ghir (35.45 psu) our reconstructed salinity is well within the calculated error estimate of \pm 0.7 psu. Following the study of Morley et al. (2011) we assumed a constant $\delta^{18} \mathrm{O}_{\text {sw }}$-salinity relationship to calculate downcore salinity values.

\section{Chronology}

The age model for OC437-7 24GGC is constrained by a combination of four accelerator mass spectrometry (AMS) radiocarbon measurements $\left({ }^{14} \mathrm{C}\right.$ ) (Lawrence Livermore National Laboratory see Table 1) and a cross correlation between magnetic susceptibility records from nearby core GeoB6007-2 $\left(30.850^{\circ} \mathrm{N}, 10.268^{\circ} \mathrm{W}\right.$; 899 m water depth) (Bleil and Dillon, 2008) and OC437-7 24GGC. The four samples for radiocarbon measurements consist of the planktonic foraminifera Globigerina bulloides picked at 32, 118, 222, and $294 \mathrm{~cm}$ depth (Table 1). All raw radiocarbon dates were converted into calendar years with the CALIB 6.1.1 software and the MARINE 09 calibration dataset (Stuiver and Reimer, 1993; Stuiver et al., 1998). We applied the implicit reservoir age correction $(\Delta R=0)$ for all dates because the precise reservoir correction for Northwest Africa is uncertain (Kim et al., 2007). In Table 1 we report the weighted mean averages (WMA) of the calibrated probability distribution for each age with their respective $2 \sigma$ confidence range.

The availability of two overlapping magnetic susceptibility records for OC437-7 24GGC and GeoB6007-2 allows us to provide additional chronological constrain for OC437-7 24GGC by tying our core to the well-dated record of GeoB6007-2 (Kuhlmann et al., 2004; Morley et al., 2011) (Fig. 3). At the core breaks magnetic susceptibility readings for OC437-7 24GGC are faulty due to the loss in density where the gravity core was cut on the ship. Accordingly we removed these values from Fig. 3. We proceeded to calculate the most significant cross correlation at zero lag for each core section of OC437-7 24GGC in relation to the well dated GeoB6007-2 record. The resultant age model confirms the chronology obtained by AMS ${ }^{14} \mathrm{C}$ dating as it places the four calibrated dates within the WMA and the $+2 \sigma$ range (Fig. 3 ). Final ages used in our age model as well as correlation coefficients between both magnetic susceptibility records are reported in Table 1 and Fig. 3. Ages between dates were obtained by linear interpolation. For the past $1.3 \mathrm{ka}$ we test this chronology by comparing $\mathrm{Mg} / \mathrm{Ca}$ values measured in H. balthica from OC437-7 24GGC with GeoB6007-2 and multicore GeoB6007-1 (Morley et al., 2011) (Fig. A1). The strong consistency in timing between the independently measured $\mathrm{Mg} / \mathrm{Ca}$ records in addition to the apparent overlap of OC437-7 24GGC with multicore GeoB6007-1 validates the age control for OC437-7 24GGC for the past $1.3 \mathrm{ka}$ and the use of a modern age for the core top. Overall, sedimentation rates range from $\sim 49$ to $55 \mathrm{~cm}$ per ka, which corresponds to a temporal resolution of $18 \pm 3$ years per $\mathrm{cm}$ (Fig. 3). By sampling one $\mathrm{cm}$ sample slices every two $\mathrm{cm}$ throughout the core, we obtained an average temporal resolution of $\sim 36$ years per sample.

\section{Results}

\subsection{Geochemical analysis on OC437-7 24GGC}

$\mathrm{Mg} / \mathrm{Ca}$ measurements based on $\mathrm{H}$. balthica reveal multidecadal to multicentennial intermediate water temperature oscillations of roughly $\pm 1{ }^{\circ} \mathrm{C}$ which exceed the propagated $\mathrm{Mg} / \mathrm{Ca}$ analytical uncertainty of $\pm 0.7^{\circ} \mathrm{C}$ (Fig. 2c). Our record documents a major 


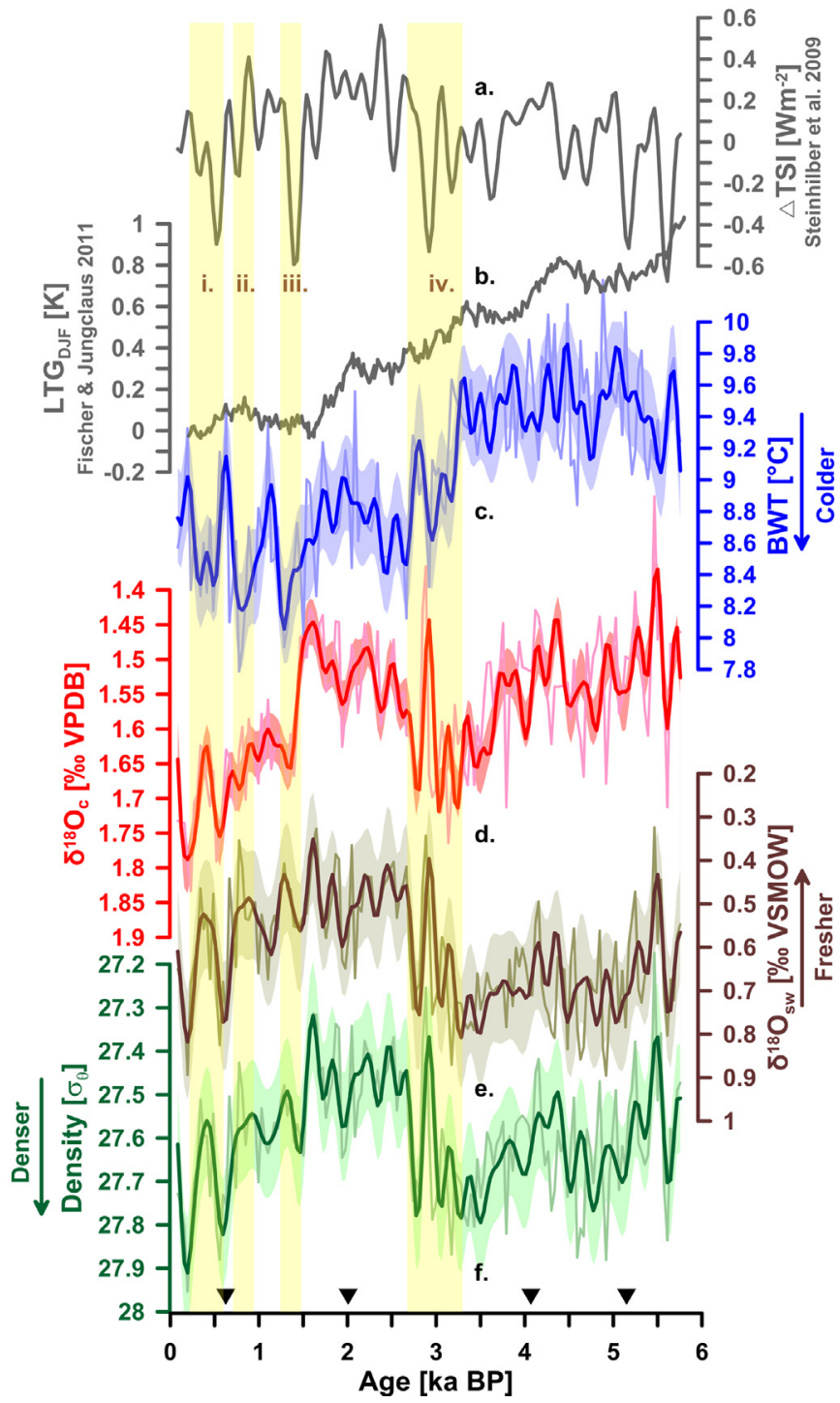

Fig. 2. ENACW properties compared to changes in LTG and $\triangle T$ TSI: Here we show (a) a 200-year low pass filter of reconstructed solar variability $\Delta$ TSI $\left[\mathrm{W} \mathrm{m}^{-2}\right.$ ] adapted from Steinhilber et al. (2009) and (b) reconstructed winter LTG (Dec-JanFeb) adapted from Fischer and Jungclaus (2011). These records are compared to ENACW properties from OC437-7 24GGC including, (c) $\mathrm{Mg} / \mathrm{Ca}$ based intermediate water temperatures (IWT), (d) measured $\delta^{18} \mathrm{O}_{\mathrm{c}}$ values, (e) calculated $\delta^{18} \mathrm{O}_{\mathrm{sw}}$ values derived from paired $\mathrm{Mg} / \mathrm{Ca}-\delta^{18} \mathrm{O}_{\mathrm{c}}$ measurements, and (f) calculated density reconstructions using modern $\delta^{18} \mathrm{O}_{\mathrm{sw}}$ - salinity relationships and $\mathrm{Mg} / \mathrm{Ca}$ derived IWT. All graphs are plotted versus age and 200-year low-pass filters are shown in bold. Also shown are the error envelopes for all 200-year low pass filtered time series. The yellow bars indicate the timing of (i) Maunder and Spör Solar Minima (LIA), (ii) Wolf Solar Minima, (iii) Dark Ages Cold Period (DACP), and (iv) the transition from the HTM to the late-Holocene. (For interpretation of the references to color in this figure legend, the reader is referred to the web version of this article.)

ENACW cooling of $1.2^{\circ} \mathrm{C}$ from $\sim 9.6^{\circ} \mathrm{C}$ to $\sim 8.6^{\circ} \mathrm{C}$ between 3.3 and $2.6 \mathrm{ka}$ (Fig. 2c) followed by distinct century scale cooling events centered at, 1.3, 0.8 and $0.4 \mathrm{ka}$. These events correspond to the commonly referenced Dark Ages Cold Period (DACP), Wolf solar minima (end of Viking colonization in Greenland), and the Maunder and Spörer solar minima or the Little Ice Age (LIA) (Fig. 2, Fig. A1). Warm intervals correspond to a plateau between 2.1 and $1.7 \mathrm{ka}$ the so called Roman Warm Period (RWP), and centennial warm peaks centered during solar maxima at 1.1 (Medieval Warm Period), 0.6 and $0.2 \mathrm{ka}$. In addition, we note an increase in overall variability of reconstructed temperatures, with amplitudes of just under $2{ }^{\circ} \mathrm{C}$ during the late-Holocene and of $\sim 1^{\circ} \mathrm{C}$ during the HTM. The good agreement with late-Holocene ENACW temperature re-
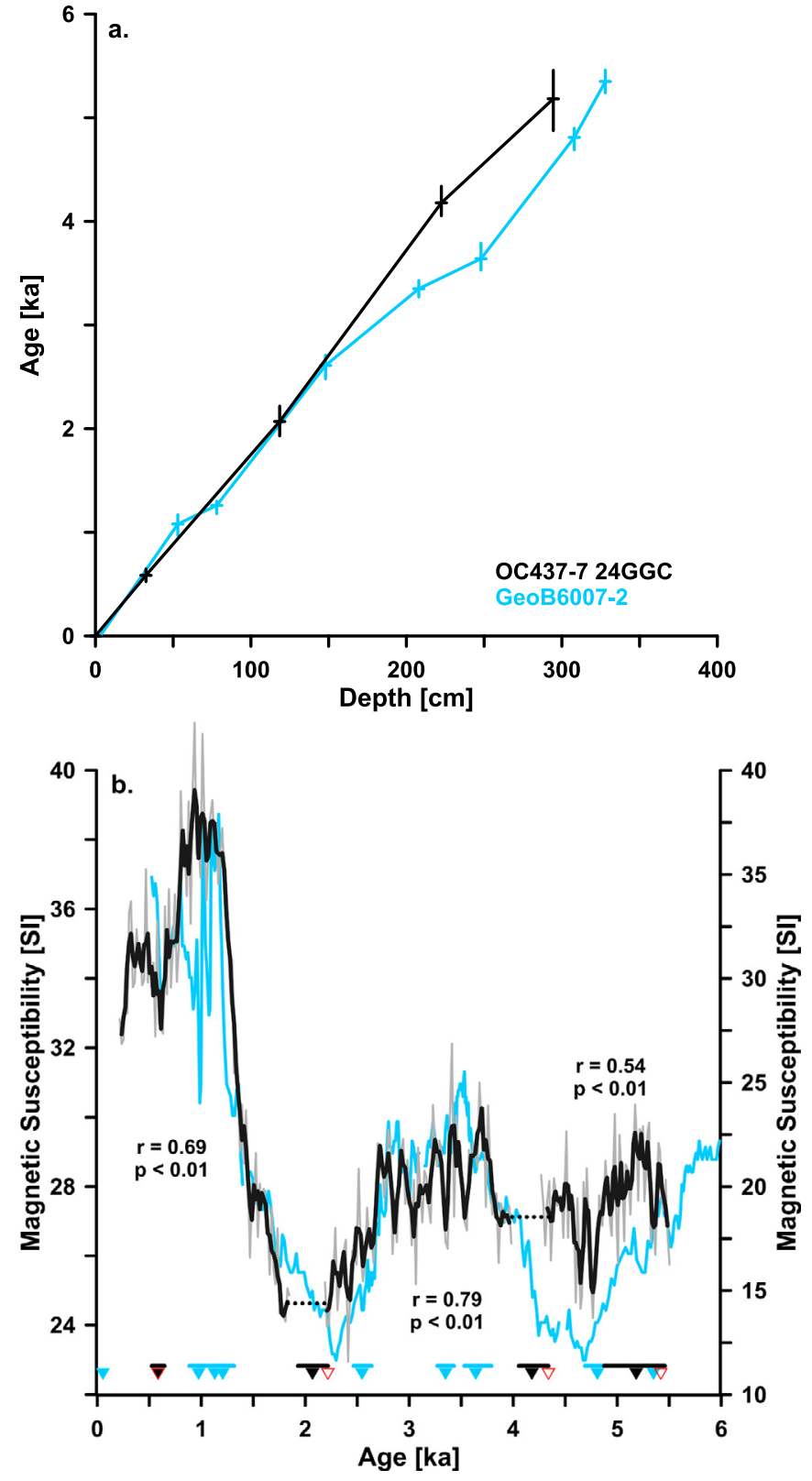

Fig. 3. Age model: In panel (a) we show the age-depth relationship between calibrated AMS ${ }^{14} \mathrm{C}$ radiocarbon dates $( \pm 2 \sigma)$ and sediment core depth for both OC437-7 24GGC (black) and GeoB6007-2 (light blue). In panel (b) we compare two magnetic susceptibility records from OC437-7 24GGC in grey (5 point moving average in black) and GeoB6007-2 (light blue). The black dotted lines shows where 0C437-7 24GGC was cut on the ship and magnetic susceptibility readings are faulty due to the loss in density at the core breaks $(10 \mathrm{~cm}$ on either side). Also included are calibrated AMS ${ }^{14} \mathrm{C}$ radiocarbon dates $( \pm 2 \sigma)$ for OC437-7 24GGC (black triangles) and GeoB6007-2 (light blue triangles) as well as final calibrated ages used for the age model (open red triangles). Correlation coefficient and $p$ values between both magnetic susceptibility records are also included. (For interpretation of the references to color in this figure legend, the reader is referred to the web version of this article.)

constructions from GeoB6007-2 (Morley et al., 2011) in both values and amplitude shows that $\mathrm{Mg} / \mathrm{Ca}$ values measured on $\mathrm{H}$. balthica tests are reproducible and reliable at the core site (Fig. A1).

Stable oxygen isotope values $\left(\delta^{18} \mathrm{O}_{\mathrm{c}}\right)$ measured on $\mathrm{H}$. balthica range between $\sim 1.8$ and $1.4 \%$ (Fig. $2 \mathrm{~d}$ ). When combined with paleotemperatures, reconstructed $\delta^{18} \mathrm{O}_{\mathrm{sw}}$ values indicate a $0.4 \%$ drop associated with the cooling between 3.3 and $2.6 \mathrm{ka}$ (Fig. 2e). Based on the modern $\delta^{18} \mathrm{O}_{\mathrm{sw}}$-salinity relationship this equates to a salinity decrease of $\sim 0.5 \mathrm{psu}$. The combination of, temperature 
and salinity results suggest a density decrease of $\sim 0.4 \sigma_{\theta}$ after the 3.3-2.6 ka transition (Fig. 2f). During all cold events of the lateHolocene ENACW tended to be fresher and lighter than during warm intervals. Superimposed on this multicentennial variability, ENACW became increasingly denser and saltier over the past $2 \mathrm{ka}$ to regain mid-Holocene values of $\sim 27.8$ in the early 20th century (Fig. 2f).

\section{Discussion}

In the following section we use our proxy ENACW record to assess the relationship between orbitally-derived changes in the latitudinal temperature gradient (LTG), ocean-atmosphere climate linkages and ENACW circulation. First, we will outline the climate response to changing LTGs at high northern latitudes by reviewing climate reconstructions of the HTM and the climate state during the 1930s (most recent example of a reduced LTG). The described climate background will then serve to test if our reconstructions are consistent with the ocean-atmosphere climate response of a changing LTG over the mid-to-late Holocene transition.

\subsection{Climate impact of changing LTGs during the mid-to-late Holocene transition}

A meridional temperature gradient arises from differential radiative heating between tropical and polar latitudes. The climate system restores this imbalance through the meridional transport of heat via atmospheric and ocean circulation systems (e.g. the intensity and position of mid-latitude storms, the tropical Hadley cell, subtropical and subpolar atmospheric pressure centers, and surface ocean gyres) that control the poleward flux of latent and sensible heat (Jain et al., 1999; Raymo and Nisancioglu, 2003; Rind, 1998). Both model analysis and proxy data suggest that peak high-latitude summer insolation and reduced low-latitude winter insolation reduced LTGs by warming the Arctic (Andersen et al., 2004a, 2004b; Calvo et al., 2002; Davis and Brewer, 2009; Jansen et al., 2009; Kerwin et al., 1999; Masson et al., 1999; Renssen et al., 2005a, 2005b; Rind, 1998; Vinther et al., 2009) and cooling the Tropics during the HTM (Bonfils et al., 2004; Davis and Brewer, 2009; Masson et al., 1999). Further, model analysis suggest that the relative decrease in winter insolation near the tropics cooled continental land masses and thereby reduced precipitation at the Intertropical Convergence Zone especially over major continents of the Atlantic sector (Brayshaw et al., 2010). As a result the Hadley Cell was narrower, shallower, and stronger during HTM winters (Brayshaw et al., 2010). The key atmospheric change caused by the modified ascent patterns of the winter Hadley Cell was the southward displacement of the Subtropical Jet Stream resulting in weaker mid-latitude storm intensities (Brayshaw et al., 2010; Renssen et al., 2005a, 2005b) and a more southerly position of winter storm tracks. In a positive feedback loop, weaker storm intensities reduced wind-stress, sea surface heat loss (evaporation), and moisture content in the atmosphere, which further weakened mid-latitude storm intensities (Bonfils et al., 2004; Brayshaw et al., 2010; Jansen et al., 2009). In addition to these model analysis, southern European pollen data sets, North African lake level records and archaeological reconstructions support the suggested southward displacement of winter storm tracks resulting in cooler and wetter Mediterranean and North African winters during the HTM (Bonfils et al., 2004; Kropelin et al., 2008; Kuper and Kropelin, 2006; Masson et al., 1999).

\subsection{Modern analogue to a weak LTG}

Computing LTGs over the past 130 years allows us to examine associated historical changes in atmospheric circulation patterns

\section{Change in Latitudinal Temperature Gradient $64-90^{\circ} \mathrm{N}$ minus $0-24^{\circ} \mathrm{N}$}

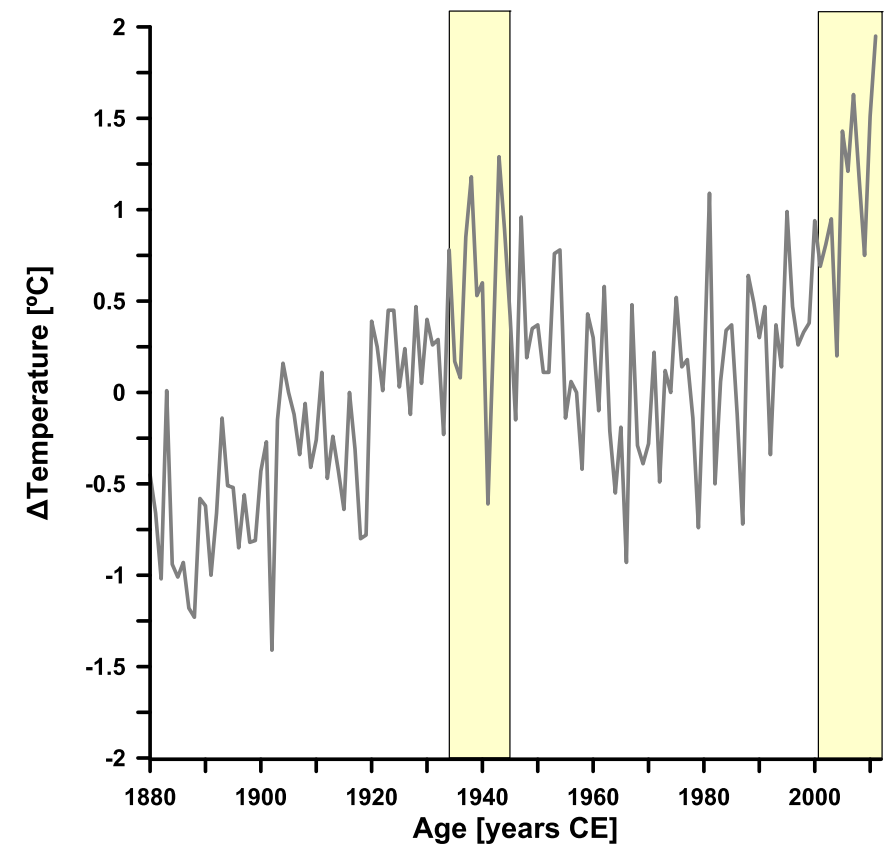

Fig. 4. Changes in the observed latitudinal temperature gradient are calculated by subtracting latitudinal temperature anomalies between $64^{\circ}-90^{\circ} \mathrm{N}$ and $0^{\circ}-24^{\circ} \mathrm{N}$, since 1880 . The yellow bars indicate the weak LTG during the 1930s and more recently from 2000-2012 (e.g. when the temperature difference between the high Arctic and the tropics was smallest). These are also the periods when polar and subpolar latitudes experience enhanced warming and the link between the NAO and Westerlies breaks down. Data obtained from the Goddard Institute for Space Studies (GISS) Surface Temperature Analysis (GISTEMP). The base period for anomaly calculations was set between 1951 and 1980. Positive (negative) values reflect weaker (stronger) LTGs relative to this time interval. (For interpretation of the references to color in this figure legend, the reader is referred to the web version of this article.)

over the instrumental record. Fig. 4 illustrates two prominent decreases in LTGs over the past century centered during the 1930s and more recently during the past decade. Both periods are characterized by extensive high latitude warming $\left(2.2^{\circ} \mathrm{C}\right)$ with the largest changes occurring north of $60^{\circ} \mathrm{N}$ (Polyakov et al., 2003) leading to Arctic and subarctic sea-ice retreat and elevated SSTs during the winter (Overland and Wang, 2005). Most of the observed warming was linked to a westward extension of the Siberian High allowing anomalous southeasterly winds into the Bering Sea warming SSTs and delaying winter sea ice formation (Fig. 5) (Cassou et al., 2004; Overland and Wang, 2005; Wood and Overland, 2010). Over subpolar latitudes, an eastward shift and heightening of the Icelandic Low weakened pressure gradients between the Greenland High and the Icelandic Low reducing northerly winds along the east Greenland coastline and thereby the strength of the East Greenland Current (EGC) (Blindheim and Malmberg, 2005). The weaker EGC/Icelandic Low allowed the Irminger Current (IC) to penetrate further north into the Denmark Strait (Fig. 6b) (Beverton and Lee, 1965; Dickson and Brander, 1993; Kushnir, 1994) warming surface waters off southeast Greenland and northern Iceland by $\sim 2{ }^{\circ} \mathrm{C}$ during the 1930 s to late 1950 s (NOAA_ERSST_V3; Smith et al., 2008; Xue et al., 2003). The northward penetration of IC waters into the Denmark Strait was favored by a weak SPG circulation, a north-south gyre orientation and a northwestward retreat of the Subarctic front (SAF) (Fig. 6b). A Strong east-west oriented SPG on the other hand favors the inflow of EGC waters into the Irminger and Iceland Seas and a southeastern advance of the SAF (Fig. 6a) (Bersch et al., 1999; Flatau et al., 2003; Hatun et al., 2005). 

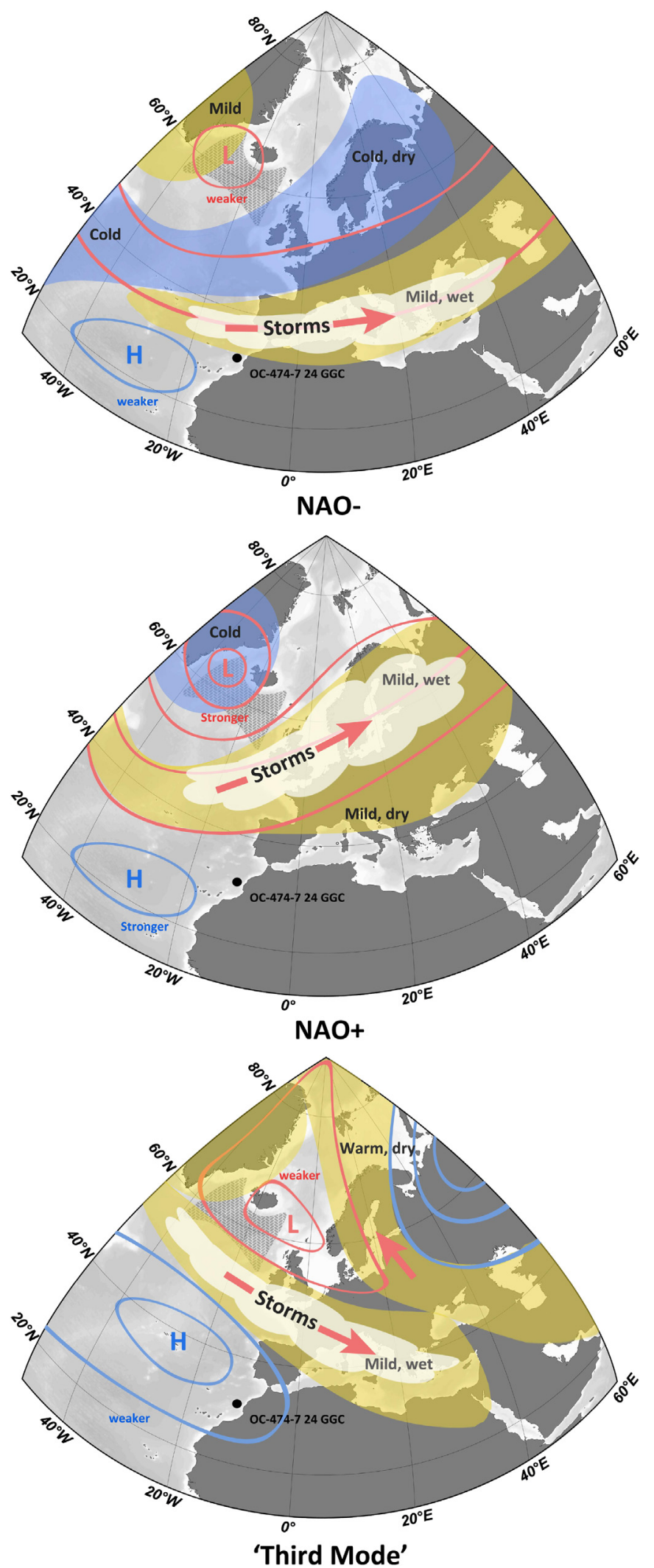

Fig. 5. Comparison of the NAO (top and middle) dipole with the atmospheric configuration of the 1930s (bottom): The bottom panel illustrates the distribution of atmospheric pressure centers and climate over Northern Latitudes during the 1930s atmospheric regime shift as described by Overland and Wang (2005). In addition, all panels show the ENACW formation region marked in grey hatching and core location of OC437-7 24GGC (adapted from McCartney and Talley, 1982).
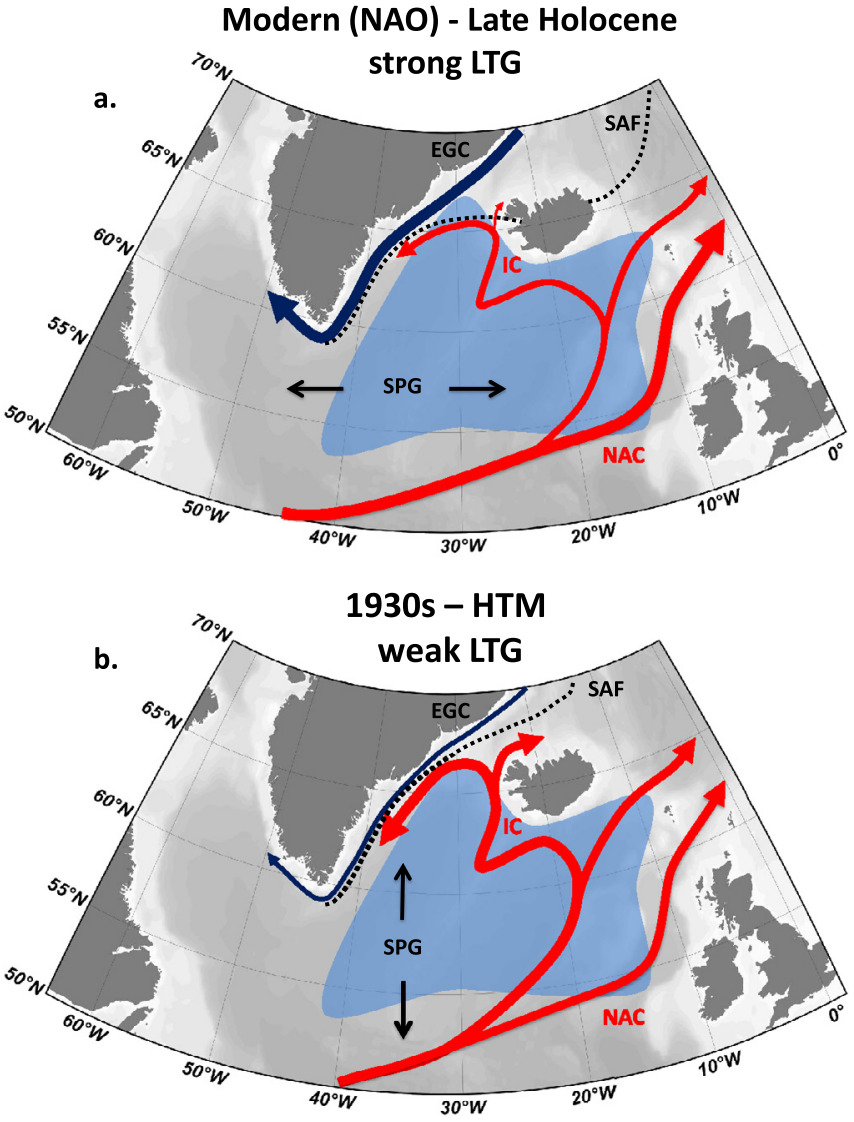

Fig. 6. Schematic representation subpolar gyre surface currents and the location of the Subarctic Front (SAF). Pannel (a) shows the modern position of the SAF and a strong east-west oriented SPG favoring the inflow of Atlantic waters into the Nordic Seas in lieu of the IC. In panel (b) we show how a weaker north-south oriented SPG during the 1930s favored the inflow of Atlantic water into the IC and Denmark Strait. Similar to Fig. 1 both panels show the ENACW formation region (light blue) (adapted from McCartney and Talley, 1982). (For interpretation of the references to color in this figure legend, the reader is referred to the web version of this article.)

\subsection{Dynamical feedback mechanisms due to a change in LTG}

Taking both model experiments and observational data into account, the climate responses of a weaker LTG in the North Atlantic basin are: (1) Reduced high latitude sea ice extent, (2) a decline and southward shift of mid-latitude storm tracks, and (3) a weak (north-south oriented) SPG. Assuming that the 1930s oceanatmosphere configuration is a useful analog for the decrease in LTG during the HTM, we would expect to see the following trends in paleoceanographic records: (1) high latitude sea surface warming and reduced winter sea ice extent in the Barents Sea, (2) reduced sea surface heat loss, warming, and a northwestward retreat of the SAF north of the Denmark Strait; and (3) as a result of (2) warmer and saltier ENACW during the HTM.

In support of the proposed mechanism, paleoclimate reconstructions from Scandinavian Europe and the Barents Sea provide evidence for warmer $\left(2-4{ }^{\circ} \mathrm{C}\right)$ and dryer winters during the HTM (Bakke et al., 2008; Kerwin et al., 1999; Seppä et al., 2005). The delayed seasonal production of sea ice (Kerwin et al., 1999) and overall reduced sea ice extent in the Barents Sea (Andersen et al., 2004a; Koç et al., 1993; Polyak and Mikhailov, 1996; Voronina et al., 2001) indicates that the combined effect of warmer surface air and SSTs permanently pushed the polar front north of its modern position in the Barents Sea, further contributing to warmer winters via the sea ice - albedo feedback during the HTM. The combination of both warmer and dryer winters in Northern Europe is at odds with the typical NAO-AMO type climate signature, which would 
bring either cold and dry (NAO -) or warm and wet $(\mathrm{NAO}+$ ) winters to this region (Fig. 5). Alternatively, an atmospheric circulation regime similar to the 1930 s with a westward extension of the Siberian High and anomalous southeasterly winds (Fig. 5) would be able to explain observations of warmer and dryer winters over Northern Europe and the Bering Sea during the HTM.

Paleoreconstructions of surface water properties in the Denmark Strait region mark a distinct shift from warm and saline surface waters of subtropical origins to cool and fresher polar waters after the mid-to-late Holocene transition (Giraudeau et al., 2010; Ólafsdóttir et al., 2010). There is common consensus that a stronger influence of the EGC in the Irminger and Iceland Seas coupled with a southeastward advance of the SAF and a stronger east-west oriented SPG were responsible for this shift (Fig. 6b) (Giraudeau et al., 2000; Jennings et al., 2011; Ólafsdóttir et al., 2010; Solignac et al., 2004). Thornalley et al. (2009) discuss the processes responsible for a shift from a weak north-south oriented (e.g. HTM) to a strong east-west oriented SPG (e.g. lateHolocene) and identify local wind stress as the controlling mechanism for SPG strength and orientation (Häkkinen and Rhines, 2004; Thornalley et al., 2009). If this hypothesis is correct westerly winds were weaker over the Irminger and Iceland Seas during the HTM and increased over the mid-to-late Holocene transition into the late-Holocene. An intensification of mid-latitude storm intensities agrees well with the predicted model response to a strengthening of LTG during the late-Holocene (Brayshaw et al., 2010; Renssen et al., 2005a, 2005b).

The influence of stronger sea surface heat loss (mid-latitude Westerlies) and the southeastern advance of the SAF is captured by a $1.2{ }^{\circ} \mathrm{C}$ and $0.4 \%$ drop in ENACW temperature and $\delta^{18} \mathrm{O}_{\text {sw }}$ values over the mid-to-late Holocene transition. Similarly, several paleoceanographic datasets from subpolar latitudes record a shift in EGC/IC strength after 4 ka (Farmer et al., 2011; Hall et al., 2004; Moros et al., 2012; Thornalley et al., 2009) indicating that the SAF reached its modern position across the Denmark Strait after the mid-to-late Holocene transition (Berner et al., 2008; Giraudeau et al., 2000; Hall et al., 2004; Moros et al., 2012; Rasmussen et al., 2002). Additional evidence for fresher subpolar surface waters also come from the Denmark Strait after $4 \mathrm{ka}$ (Ólafsdóttir et al., 2010) and the Reykjanes Ridge after $3.7 \mathrm{ka}$ (Came et al., 2007).

Morley et al. (2011) discussed the sensitivity of ENACW circulation to solar variability on multidecadal to centennial timescales over the past $1.3 \mathrm{ka}$. Fig. 2 suggests that the sensitivity of ENACW circulation to solar variability increased during the late-Holocene with temperature amplitudes of just under $2^{\circ} \mathrm{C}$ especially after 1.5 ka compared to $1^{\circ} \mathrm{C}$ changes during the HTM. Similarly, several other paleoceanographic records (Andersen et al., 2004a; Calvo et al., 2002; Jansen et al., 2009; Moros et al., 2012; Rasmussen et al., 2002) also discuss an increase in climate sensitivity or variability of subpolar and polar sea surface ocean properties during the late-Holocene. In a coupled climate model Renssen et al. (2005b) explain this increase in climate sensitivity by linking the expansion of high latitude sea ice formation and enhanced sea ice export along the East Greenland margin with stronger temperature and salinity gradients north and south of the SAF after $4 \mathrm{ka}$. This gradual increase in gradients potentially forced higher amplitude shifts of the SAF (Renssen et al., 2005b) resulting in the increased sensitivity observed in subpolar surface ocean properties to solar forcing during the late-Holocene. The combined effect of (1) stronger midlatitude Westerlies, (2) a strong east-west oriented SPG with a SAF located across the Denmark Strait and (3) high amplitude swings of the SAF thus provide an explanation for the increased sensitivity of ENACW circulation to solar variability during the late-Holocene.

In addition to the apparent amplification of climate variability after the mid-to-late Holocene transition we also record a trend towards denser EANCW that is linked to increasing $\delta^{18} \mathrm{O}_{\mathrm{sw}}$ values over the past $3 \mathrm{ka}$ and especially after $1.5 \mathrm{ka}$. There are two possible mechanisms that could have increased salinity values in subpolar surface waters during the late-Holocene. The inflow of fresh EGC waters into the SPG may have progressively decreased, or the influence of warm and saline subtropical waters progressively increased over the past $3 \mathrm{ka}$. Our discussion highlights the unlikely scenario of a weaker or saltier EGC during the late-Holocene. On the other hand, several SPG thermocline records provide evidence for a seasonal (summer) thermocline warming trend after the HTM (Farmer et al., 2011; Hall et al., 2004; Moros et al., 2012; Thornalley et al., 2009). It is therefore more likely that the observed trend in $\delta^{18} \mathrm{O}_{\mathrm{sw}}$ values was linked to the overall increase in northward transport of warm and saline Atlantic waters during Holocene (Farmer et al., 2011; Hall et al., 2004; Moros et al., 2012; Thornalley et al., 2009). Interestingly, the salinity trend in the ENACW record is not paralleled by warmer temperatures over the same interval. This decoupling between temperature and salinity may also be linked to two processes. Either sea surface heat loss associated with stronger mid-latitude Westerlies counteracted the warming brought in by Atlantic waters or enhanced sea ice export along the East Greenland margin cooled but not significantly freshened SPMW over the past $3 \mathrm{ka}$.

\section{Conclusions}

Observations at subpolar latitudes provide us with a detailed account of ocean-atmospheric circulation changes over the mid-tolate Holocene transition. Our analysis suggests that westerly winds over subpolar latitudes were weaker during HTM winters, indicating that the Icelandic Low was weaker and/or shifted in location relative to today. As a result, SPG circulation strength was weaker allowing warm and salty Atlantic waters (IC) to influence northeastern SPG surface water properties during the HTM. Compared to modern observations such a climate signature in ENACW properties is typically recorded during negative NAO years (Johnson and Gruber, 2007; Morley et al., 2011). However, NAO (-) like atmospheric circulation patterns are unlikely to have caused warm and dry conditions in Northern Europe and the Barents Sea during the HTM. Instead a 1930s-like atmospheric circulation regime might best reconcile climate records from both Northern Europe and subpolar latitudes.

Finally, the presented data illustrates the dynamic response of ENACW circulation to a gradual change in the LTG during the midto-late Holocene transition. This ocean-atmosphere response is a prime example of an amplifying feedback mechanism within the climate system and its identification will help to advance our understanding of how regional climate change is transferred and amplified to affect hemispheric wide climate linkages.

\section{Acknowledgements}

We would like to thank the editor and two anonymous reviewers for thoughtful discussion and comments. Core OC437-7 24GGC was collected as part of the Changing Holocene Environments of the Eastern Topical Atlantic (CHEETA) coring transect along NW Africa and was supported by NSF award OCE04-02348 to PdeM and Tim Eglinton. We acknowledge the exceptional efforts of the captain, crew and shipboard scientists abroad the R/V Oceanus. Additional support came from NSF award OCE0902977 to YR.

\section{Appendix A. Supplementary material}

Supplementary material related to this article can be found online at http://dx.doi.org/10.1016/j.epsl.2013.11.039. 


\section{References}

Ammann, C.M., Joos, F., Schimel, D.S., Otto-Bliesner, B.L., Tomas, R.A., 2007. Solar influence on climate during the past millennium: Results from transient simulations with the NCAR Climate System Model. Proc. Natl. Acad. Sci. USA 104, 3713-3718.

Andersen, C., Koç, N., Jennings, A., Andrews, J.T., 2004a. Nonuniform response of the major surface currents in the Nordic Seas to insolation forcing: Implications for the Holocene climate variability. Paleoceanography 19, 2003.

Andersen, C., Koç, N., Moros, M., 2004b. A highly unstable Holocene climate in the subpolar North Atlantic: evidence from diatoms. Quat. Sci. Rev. 23, 2155-2166.

Arhan, M., Colin De Verdiére, A., Mémery, L., 1994. The eastern boundary of the subtropical North Atlantic. J. Phys. Oceanogr. 24, 1295-1316.

Bakke, J., Lie, Ø., Dahl, S.O., Nesje, A., Bjune, A.E., 2008. Strength and spatial patterns of the Holocene wintertime westerlies in the NE Atlantic region. Glob. Planet. Change 60, 28-41.

Barker, S., Greaves, M., Elderfield, H., 2003. A study of cleaning procedures used for foraminiferal Mg/Ca paleothermometry. Geochem. Geophys. Geosyst. 4, 8407.

Bengtsson, L., Semenov, V.A., Johannessen, O.M., 2004. The early twentieth-century warming in the Arctic-a possible mechanism. J. Climate 17, 4045-4057.

Berner, K.S., Koç, N., Divine, D., Godtliebsen, F., Moros, M., 2008. A decadal-scale Holocene sea surface temperature record from the subpolar North Atlantic constructed using diatoms and statistics and its relation to other climate parameters. Paleoceanography 23, PA2210.

Bersch, M., Meincke, J., Sy, A., 1999. Interannual thermohaline changes in the northern North Atlantic 1991-1996. Deep-Sea Res., Part 2, Top. Stud. Oceanogr. 46, 55-75.

Beverton, R., Lee, A., 1965. Hydrographic fluctuations in the North Atlantic Ocean and some biological consequences. Symp. Inst. Biol. 14, 79-109.

Bleil, U., Dillon, M., 2008. Holocene Earth's magnetic field variations recorded in marine sediments of the NW African continental margin. Stud. Geophys. Geod. 52, 133-155.

Blindheim, J., Malmberg, S.A., 2005. The mean sea level pressure gradient across the Denmark Strait as an indicator of conditions in the North Icelandic Irminger current, The Nordic Seas: An integrated perspective oceanography. In: Climatology, Biogeochemistry, and Modeling. AGU, Washington, DC, pp. 65-71.

Bonfils, C., de Noblet-Ducoudré, N., Guiot, J., Bartlein, P., 2004. Some mechanisms of mid-Holocene climate change in Europe, inferred from comparing PMIP models to data. Clim. Dyn. 23, 79-98.

Booth, B.B.B., Dunstone, N.J., Halloran, P.R., Andrews, T., Bellouin, N., 2012. Aerosols implicated as a prime driver of twentieth-century North Atlantic climate variability. Nature 484, 228-232.

Brayshaw, D.J., Hoskins, B., Black, E., 2010. Some physical drivers of changes in the winter storm tracks over the North Atlantic and Mediterranean during the Holocene. Philos. Trans. R. Soc. A, Math. Phys. Eng. Sci. 368, 5185-5223.

Calvo, E., Grimalt, J., Jansen, E., 2002. High resolution U37K sea surface temperature reconstruction in the Norwegian Sea during the Holocene. Quat. Sci. Rev. 21, 1385-1394.

Came, R.E., Oppo, D.W., McManus, J.F., 2007. Amplitude and timing of temperature and salinity variability in the subpolar North Atlantic over the past 10 k.y. Geology 35, 315-318.

Cassou, C., Terray, L., Hurrell, J.W., Deser, C., 2004. North Atlantic winter climate regimes: spatial asymmetry, stationarity with time, and oceanic forcing. J. Climate 17, 1055-1068.

Davis, B., Brewer, S., 2009. Orbital forcing and role of the latitudinal insolation/temperature gradient. Clim. Dyn. 32, 143-165.

De Angelis, M., Steffensen, J.P., Legrand, M., Clausen, H., Hammer, C., 1997. Primary aerosol (sea salt and soil dust) deposited in Greenland ice during the last climatic cycle: Comparison with east Antarctic records. J. Geophys. Res. 102, 26681-26698.

Dickson, R.R., Brander, K.M., 1993. Effects of a changing windfield on cod stocks of the North Atlantic. Fish. Oceanogr. 2, 124-153.

Drinkwater, K.F., 2006. The regime shift of the 1920s and 1930s in the North Atlantic. Prog. Oceanogr. 68, 134-151.

Farmer, E.J., Chapman, M.R., Andrews, J.E., 2011. Holocene temperature evolution of the subpolar North Atlantic recorded in the $\mathrm{Mg} / \mathrm{Ca}$ ratios of surface and thermocline dwelling planktonic foraminifers. Glob. Planet. Change 79, 234-243.

Fischer, N., Jungclaus, J.H., 2011. Evolution of the seasonal temperature cycle in a transient Holocene simulation: orbital forcing and sea-ice. Clim. Past 7, 1139-1148.

Flatau, M.K., Talley, L., Niiler, P.P., 2003. The North Atlantic oscillation, surface current velocities, and SST changes in the subpolar North Atlantic. J. Climate 16, 2355-2369.

Furevik, T., Nilsen, J.E., 2005. Large-scale circulation variability and its impacts on the Nordic Seas ocean climate - a review. In: Drange, H., Dokken, T., Furevik, T., Gerdes, R., Berger, W. (Eds.), The Nordic Seas: An Integrated Perspective Oceanography, Climatology, Biogeochemistry and Modelling. The American Geophysical Unioin, Washington, DC, pp. 105-136.

Giraudeau, J., Cremer, M., Manthé, S., Labeyrie, L., Bond, G., 2000. Coccolith evidence for instabilities in surface circulation south of Iceland during Holocene times. Earth Planet. Sci. Lett. 179, 257-268.
Giraudeau, J., Grelaud, M., Solignac, S., Andrews, J.T., Moros, M., Jansen, E., 2010. Millennial-scale variability in Atlantic water advection to the Nordic Seas derived from Holocene coccolith concentration records. Quat. Sci. Rev. 29, 1276-1287.

Grossmann, I., Klotzbach, P.J., 2009. A review of North Atlantic modes of natural variability and their driving mechanisms. J. Geophys. Res., Atmos. 114, D24107.

Häkkinen, S., 2000. Decadal air-sea interaction in the North Atlantic based on observations and modeling results. J. Climate 13, 1195-1219.

Häkkinen, S., Rhines, P.B., 2004. Decline of subpolar North Atlantic circulation during the 1990 s. Science $304,555-559$.

Hall, I.R., Bianchi, G.G., Evans, J.R., 2004. Centennial to millennial scale Holocene climate-deep water linkage in the North Atlantic. Quat. Sci. Rev. 23, 1529-1536.

Hatun, H., Sando, A.B., Drange, H., Hansen, B., Valdimarsson, H., 2005. Influence of the Atlantic subpolar gyre on the thermohaline circulation. Science 309, 1841-1844.

Hurrell, J.W., 1995. Decadal tends in the North Atlantic oscillation: regional temperatures and precipitation. Science 269, 676-679.

Iselin, C.O.D., 1936. A study of the circulation of the western North Atlantic. Pap. Phys. Oceanogr. Meteorol. 4, 101.

Jain, S., Lall, U., Mann, M.E., 1999. Seasonality and interannual variations of northern hemisphere temperature: Equator-to-pole gradient and ocean-land contrast. J. Climate 12, 1086-1100.

Jansen, E., Andersson, C., Moros, M., Nisancioglu, K.H., Nyland, B.F., Telford, R.J., 2009. The Early to Mid-Holocene Thermal Optimum in the North Atlantic, Natural Climate Variability and Global Warming. Wiley Blackwell, pp. 123-137.

Jennings, A., Andrews, J., Wilson, L., 2011. Holocene environmental evolution of the SE Greenland Shelf North and South of the Denmark Strait: Irminger and East Greenland current interactions. Quat. Sci. Rev. 30, 980-998.

Johnson, G.C., Gruber, N., 2007. Decadal water mass variations along $20^{\circ} \mathrm{W}$ in the Northeastern Atlantic Ocean. Prog. Oceanogr. 73, 277-295.

Keffer, T., 1985. The ventilation of the World's Oceans: Maps of the potential vorticity field. J. Phys. Oceanogr. 15, 509-523.

Kerwin, M.W., Overpeck, J.T., Webb, R.S., DeVernal, A., Rind, D.H., Healy, R.J., 1999. The role of oceanic forcing in mid-Holocene Northern Hemisphere climatic change. Paleoceanography 14, 200.

Kim, J.-H., Meggers, H., Rimbu, N., Lohmann, G., Freudenthal, T., Muller, P.J., Schneider, R.R., 2007. Impacts of the North Atlantic gyre circulation on Holocene climate off northwest Africa. Geology 35, 387-390.

Knight, J.R., Allan, R.J., Folland, C.K., Vellinga, M., Mann, M.E., 2005. A signature of persistent natural thermohaline circulation cycles in observed climate. Geophys. Res. Lett. 32, L20708.

Knoll, M., Hernández-Guerra, A., Lenz, B., Laatzen, F.L., Machín, F., Müller, T.J., Siedler, G., 2002. The eastern boundary current system between the Canary Islands and the African Coast. Deep-Sea Res., Part 2, Top. Stud. Oceanogr. 49, 3427-3440.

Knudsen, M.F., Riisager, P., Jacobsen, B.H., Muscheler, R., Snowball, I., Seidenkrantz, M.-S., 2009. Taking the pulse of the Sun during the Holocene by joint analysis of ${ }^{14} \mathrm{C}$ and ${ }^{10} \mathrm{Be}$. Geophys. Res. Lett. 36.

Knudsen, M.F., Seidenkrantz, M.-S., Jacobsen, B.H., Kuijpers, A., 2011. Tracking the Atlantic Multidecadal Oscillation through the last 8,000 years. Nat. Commun. 2, 178.

Koç, N., Jansen, E., Haflidason, H., 1993. Paleoceanographic reconstructions of surface ocean conditions in the Greenland, Iceland and Norwegian seas through the last 14 ka based on diatoms. Quat. Sci. Rev. 12, 115-140.

Kropelin, S., Verschuren, D., Lezine, A.M., Eggermont, H., Cocquyt, C., Francus, P., Cazet, J.P., Fagot, M., Rumes, B., Russell, J.M., Darius, F., Conley, D.J., Schuster, M., von Suchodoletz, H., Engstrom, D.R., 2008. Climate-driven ecosystem succession in the Sahara: the past 6000 years. Science 320, 765-768.

Kuhlmann, H., Meggers, H., Freudenthal, T., Wefer, G., 2004. The transition of the monsoonal and the $\mathrm{N}$ Atlantic climate system off NW Africa during the Holocene. Geophys. Res. Lett. 31, L22204.

Kuper, R., Kropelin, S., 2006. Climate-controlled Holocene occupation in the Sahara: motor of Africa's evolution. Science 313, 803-807.

Kushnir, Y., 1994. Interdecadal variations in North Atlantic Sea surface temperature and associated atmospheric conditions. J. Climate 7, 141-157.

Lean, J.L., 2010. Cycles and trends in solar irradiance and climate. Wiley Interdiscip. Rev.: Clim. Change 1, 111-122.

LeGrande, A.N., Schmidt, G.A., 2006. Global gridded data set of the oxygen isotopic composition in seawater. Geophys. Res. Lett. 33, L12604.

Levitus, S., 1989. Interpentadal variability of temperature and salinity at intermediate depths of the North Atlantic Ocean, 1970-1974 versus 1955-1959. J. Geophys. Res. 94, 6091-6131.

Liu, Z., Alexander, M., 2007. Atmospheric bridge, oceanic tunnel, and global climatic teleconnections. Rev. Geophys. 45, RG2005.

Lockwood, M., Harrison, R.G., Woollings, T., Solanki, S.K., 2010. Are cold winters in Europe associated with low solar activity?. Environ. Res. Lett. 5, 024001.

Lohmann, G., Rimbu, N., Dima, M., 2004. Climate signature of solar irradiance variations: analysis of long-term instrumental, historical, and proxy data. Int. J. Climatol. 24, 1045-1056.

Luterbacher, J., Dietrich, D., Xoplaki, E., Grosjean, M., Wanner, H., 2004. European seasonal and annual temperature variability, trends, and extremes since 1500 . Science 303, 1499-1503. 
Mann, M.E., Zhang, Z., Rutherford, S., Bradley, R.S., Hughes, M.K., Shindell, D., Ammann, C., Faluvegi, G., Ni, F., 2009. Global signatures and dynamical origins of the little ice age and medieval climate anomaly. Science 326, 1256-1260.

Marshall, J., Kushnir, Y., Battisti, D., Chang, P., Czaja, A., Dickson, R., Hurrell, J., McCartney, M., Saravanan, R., Visbeck, M., 2001. North Atlantic climate variability: phenomena, impacts and mechanisms. Int. J. Climatol. 21, 1863-1898.

Masson, V., Cheddadi, R., Braconnot, P., Joussaume, S., Texier, D., PMIP participants, 1999. Mid-Holocene climate in Europe: what can we infer from PMIP modeldata comparisons?. Clim. Dyn. 15, 163-182.

McCartney, M.S., Talley, L.D., 1982. The subpolar mode water of the North Atlantic Ocean. J. Phys. Oceanogr. 12, 1169-1188.

McDowell, S., Rhines, P., Keffer, T., 1982. North Atlantic potential vorticity and its relation to the general circulation. J. Phys. Oceanogr. 12, 1417-1436.

McGee, D., deMenocal, P.B., Winckler, G., Stuut, J.-B.W., Bradtmiller, L.I., 2013. The magnitude, timing and abruptness of changes in North African dust deposition over the last 20,000 yr. Earth Planet. Sci. Lett. 371-372, 163-176.

Morley, A., Schulz, M., Rosenthal, Y., Mulitza, S., Paul, A., Rühlemann, C., 2011. Solar modulation of North Atlantic central water formation at multidecadal timescales during the late Holocene. Earth Planet. Sci. Lett. 308, 161-171.

Moros, M., Jansen, E., Oppo, D.W., Giraudeau, J., Kuijpers, A., 2012. Reconstruction of the late-Holocene changes in the Sub-Arctic Front position at the Reykjanes Ridge, North Atlantic. Holocene 22, 877-886.

Ólafsdóttir, S., Jennings, A.E., Geirsdóttir, Á., Andrews, J., Miller, G.H., 2010. Holocene variability of the North Atlantic Irminger current on the south- and northwest shelf of Iceland. Marine Micropaleontology 77, 101-118.

Olsen, J., Anderson, N.J., Knudsen, M.F., 2012. Variability of the North Atlantic Oscillation over the past 5,200 years. Nat. Geosci. 5, 808-812.

Ottera, O.H., Bentsen, M., Drange, H., Suo, L., 2010. External forcing as a metronome for Atlantic multidecadal variability. Nat. Geosci. 3, 688-694.

Overland, J.E., Wang, M., 2005. The Arctic climate paradox: The recent decrease of the Arctic Oscillation. Geophys. Res. Lett. 32, L06701.

Pena, L.D., Francés, G., Diz, P., Esparza, M., Grimalt, J.O., Nombela, M.A., Alejo, I., 2010. Climate fluctuations during the Holocene in NW Iberia: High and low latitude linkages. Cont. Shelf Res. 30, 1487-1496.

Pinto, J.G., Raible, C.C., 2012. Past and recent changes in the North Atlantic oscillation. Wiley Interdiscip. Rev.: Clim. Change 3, 79-90.

Polyak, L., Mikhailov, V., 1996. Post-glacial environments of the southeastern Barents Sea: foraminiferal evidence. Geol. Soc. (Lond.) Spec. Publ. 111, 323-337.

Polyakov, I.V., Bekryaev, R.V., Alekseev, G.V., Bhatt, U.S., Colony, R.L., Johnson, M.A., Maskshtas, A.P., Walsh, D., 2003. Variability and trends of air temperature and pressure in the Maritime Arctic, 1875-2000. J. Climate 16, 2067-2077.

Poole, R., Tomczak, M., 1999. Optimum multiparameter analysis of the water mass structure in the Atlantic Ocean thermocline. Deep-Sea Res., Part 1, Oceanogr. Res. Pap. 46, 1895-1921.

Rasmussen, T.L., Bäckström, D., Heinemeier, J., Klitgaard-Kristensen, D., Knutz, P.C., Kuijpers, A., Lassen, S., Thomsen, E., Troelstra, S.R., van Weering, T.C.E., 2002. The Faroe-Shetland Gateway: Late quaternary water mass exchange between the Nordic seas and the northeastern Atlantic. Mar. Geol. 188, 165-192.

Raymo, M.E., Nisancioglu, K., 2003. The 41 kyr world: Milankovitch's other unsolved mystery. Paleoceanography $18,1011$.

Renssen, H., Goosse, H., Fichefet, T., 2005a. Contrasting trends in North Atlantic deep-water formation in the Labrador Sea and Nordic Seas during the Holocene. Geophys. Res. Lett. 32, L08711.

Renssen, H., Goosse, H., Fichefet, T., Brovkin, V., Driesschaert, E., Wolk, F., 2005b. Simulating the Holocene climate evolution at northern high latitudes using a coupled atmosphere-sea ice-ocean-vegetation model. Clim. Dyn. 24, 23-43.

Rimbu, N., Lohmann, G., Kim, J.-H., Arz, H.W., Schneider, R., 2003. Arctic/North Atlantic Oscillation signature in Holocene sea surface temperature trends as obtained from alkenone data. Geophys. Res. Lett. 30, 1280.

Rimbu, N., Lohmann, G., Lorenz, S.J., Kim, J.H., Schneider, R.R., 2004. Holocene climate variability as derived from alkenone sea surface temperature and coupled ocean-atmosphere model experiments. Clim. Dyn. 23, 215-227.

Rind, D., 1998. Latitudinal temperature gradients and climate change. J. Geophys. Res. 103, 5943-5971.

Rosenthal, Y., Field, M.P., Sherrell, R.M., 1999. Precise determination of element/calcium ratios in calcareous samples using sector field inductively coupled plasma mass spectrometry. Anal. Chem. 71, 3248-3253.
Rosenthal, Y., Morley, A., Barras, C., Katz, M.E., Jorissen, F., Reichart, G.-J., Oppo, D.W. Linsley, B.K., 2011. Temperature calibration of $\mathrm{Mg} / \mathrm{Ca}$ ratios in the intermediate water benthic foraminifer Hyalinea balthica. Geochem. Geophys. Geosyst. 12 Q04003.

Schmiedl, G., de Bovée, F., Buscail, R., Charrière, B., Hemleben, C., Medernach, L. Picon, P., 2000. Trophic control of benthic foraminiferal abundance and microhabitat in the bathyal Gulf of Lions, western Mediterranean Sea. Marine Micropaleontology 40, 167-188.

Seppä, H., Hammarlund, D., Antonsson, K., 2005. Low-frequency and high-frequency changes in temperature and effective humidity during the Holocene in southcentral Sweden: implications for atmospheric and oceanic forcings of climate Clim. Dyn. 25, 285-297.

Shackleton, N., 1974. Attainment of isotopic equilibrium between ocean water and the benthonic foraminifera genus Uvigerina: Isotopic changes in the ocean during the last glacial. Colloq. Int. Cent. Natl. Rech. Sci. 219, 203-209.

Shindell, D.T., Schmidt, G.A., Mann, M.E., Rind, D., Waple, A., 2001. Solar forcing of regional climate change during the Maunder Minimum. Science 294, 2149-2151.

Sicre, M.A., Hall, I.R., Mignot, J., Khodri, M., Ezat, U., Truong, M.X., Eiríksson, J., Knudsen, K.L., 2011. Sea surface temperature variability in the subpolar Atlantic over the last two millennia. Paleoceanography 26, PA4218.

Smith, T.M., Reynolds, R.W., Peterson, T.C., Lawrimore, J., 2008. Improvements to NOAA's historical merged land-ocean surface temperature analysis (1880-2006). J. Climate 21, 2283-2296.

Solignac, S., de Vernal, A., Hillaire-Marcel, C., 2004. Holocene sea-surface conditions in the North Atlantic-contrasted trends and regimes in the western and eastern sectors (Labrador Sea vs. Iceland Basin). Quat. Sci. Rev. 23, 319-334.

Steinhilber, F., Abreu, J.A., Beer, J., Brunner, I., Christl, M., Fischer, H., Heikkilä, U., Kubik, P.W., Mann, M., McCracken, K.G., Miller, H., Miyahara, H., Oerter, H., Wilhelms, F., 2012. 9,400 years of cosmic radiation and solar activity from ice cores and tree rings. Proc. Natl. Acad. Sci. USA 109, 5967-5971.

Steinhilber, F., Beer, J., Fröhlich, C., 2009. Total solar irradiance during the Holocene Geophys. Res. Lett. 36, L19704.

Stuiver, M., Reimer, P.J., 1993. Extended ${ }^{14} \mathrm{C}$ data-base and revised calib. $3.0{ }^{14} \mathrm{C}$ age calibration program. Radiocarbon 35, 215-230.

Stuiver, M., Reimer, P.J., Bard, E., Beck, W., Burr, G.S., Hughen, K.A., Kromer, B., McCormac, G., van der Plicht, J., Spurk, M., 1998. INTCAL98 radiocarbon age calibration, 24,000-0 cal BP. Radiocarbon 40, 1041-1083.

Swingedouw, D., Terray, L., Cassou, C., Voldoire, A., Salas-Mélia, D., Servonnat, J. 2010. Natural forcing of climate during the last millennium: fingerprint of solar variability. Clim. Dyn.

Thornalley, D.J.R., Elderfield, H., McCave, I.N., 2009. Holocene oscillations in temperature and salinity of the surface subpolar North Atlantic. Nature 457, 711-714.

Tomczak, M., Godfrey, J.S., 1994. Regional Oceanography. Pergamon, Oxford.

Trouet, V., Esper, J., Graham, N.E., Baker, A., Scourse, J.D., Frank, D.C., 2009. Persistent positive North Atlantic oscillation mode dominated the medieval climate anomaly. Science 324, 78-80.

Villanueva Guimerans, P., Cervera Currado, J.L., 1999. Distribution of Planorbulinacea (benthic foraminifera) assemblages in surface sediments on the northern margin of the Gulf of Cadiz. Bol. Inst. Esp. Oceanogr. 15, 181-190.

Vinther, B.M., Buchardt, S.L., Clausen, H.B., Dahl-Jensen, D., Johnsen, S.J., Fisher, D.A., Koerner, R.M., Raynaud, D., Lipenkov, V., Andersen, K.K., Blunier, T., Rasmussen, S.O., Steffensen, J.P., Svensson, A.M., 2009. Holocene thinning of the Greenland ice sheet. Nature 461, 385-388.

Visbeck, M., Chassignet, E., Curry, R., Delworth, T., Dickson, B., Krahmann, G., 2003. The Ocean's response to North Atlantic oscillation variability. In: Hurrell, J.W. Kushnir, Y., Ottersen, G., Visbeck, M. (Eds.), The North Atlantic Oscillation. AGU, pp. 113-146.

Voronina, E., Polyak, L., Vernal, A.D., Peyron, O., 2001. Holocene variations of seasurface conditions in the southeastern Barents Sea, reconstructed from dinoflagellate cyst assemblages. J. Quat. Sci. 16, 717-726.

Wanner, H., Beer, J., Bütikofer, J., Crowley, T.J., Cubasch, U., Flückiger, J., Goosse, H. Grosjean, M., Joos, F., Kaplan, J.O., Küttel, M., Müller, S.A., Prentice, I.C., Solomina, O., Stocker, T.F., Tarasov, P., Wagner, M., Widmann, M., 2008. Mid- to Late Holocene climate change: an overview. Quat. Sci. Rev. 27, 1791-1828.

Wood, K.R., Overland, J.E., 2010. Early 20th century Arctic warming in retrospect. Int. J. Climatol. 30, 1269-1279.

Xue, Y., Smith, T.M., Reynolds, R.W., 2003. Interdecadal changes of 30-yr SST normals during 1871-2000. J. Climate 16, 1601-1612. 